\title{
Exhibition Review: Last Supper in Pompeii - Too much death, not enough food
}

Edward Summers, Sabah Nawaz, Elysia Dale, George Seager, Peter Novis, Millie Coster, Matthew Jenkins, Cameron Hill and Daisy Sutherland, University of Warwick, Coventry

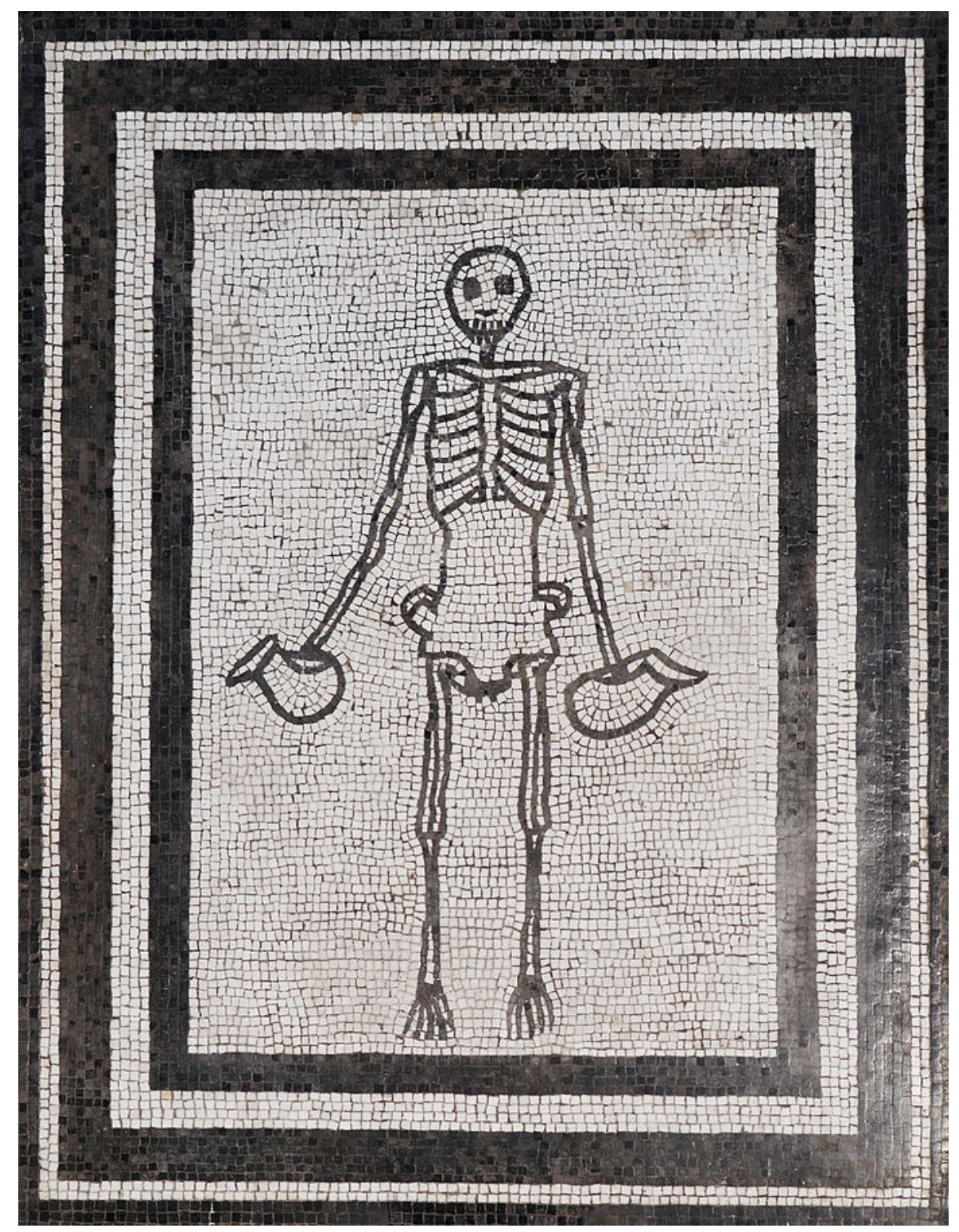

Figure 1: Mosaic of skeleton carrying wine jugs, Naples Museum inv. 9978, from Pompeii

The Ashmolean's Last Supper in Pompeii exhibition is a satisfying dish, but could have done with the cutting of a little fat. The exhibition presents, with the tragic end of the city hanging over it, a broad image of diets, dining, the production and selling of food and the links between death and consumption in ancient Pompeii. It is a topic that is 
under-represented in popular perceptions of the ancient world, but the exhibition does an admirable job of ensuring that what could be a dry presentation is consistently thought-provoking and fun. Varied forms of evidence (such as carbonised food remains, mosaics, frescos and eating utensils) keep the exhibition engaging, making each room distinct to the palate as you move through them. It gives the feeling of travelling through streets where you pass by new aspects of the Roman diet as you travel. As a whole, the ideas presented seem fully realised.

But herein lies the problem with the Last Supper in Pompeii; while the menu has a great deal to offer, there were some items on display that stood out as unnecessary to the exhibit's stated goal. A prime example was the resin cast (filled from a mould of a woman in her dying moments) - something that would turn anyone off their food. It is a fair assessment to say that when one speaks of Pompeii, one thinks of bodies; yet in this exhibition such a thing felt unnecessary and detracted from the exhibition's aims. That's not to say that the cast did not help the viewer to understand how real the disaster of Pompeii was - but does such a thing really help a visitor appreciate the city's food and drink, or is it merely a shocking distraction?

The exhibits that focused on Roman Britain provided a satisfying contrast with those from Pompeii. Not everywhere across the Roman Empire had such opulence, and the section on Roman Britain showed a more humble approach to the themes presented earlier. The walls were black and small lights were the only source of illumination throughout this area, creating a distinct sense of otherness and separation from the liveliness of Pompeii. The first sight was a tombstone, a humble soldier's memorial, whereby the visitor was led towards death as a theme in the Roman world. The rooms were structured in such a way as to narrow vision; ultimately, it becomes quite easy to stumble upon the wretched Lady of Oplontis cast, presented in total isolation, left only to speak for the pathos of itself. The cast itself as the final piece can be seen in this light as powerful - a final statement on the tragedy at Pompeii that is certain to stick in the viewer's mind long after. To contrast such grotesque imagery with the liveliness of dining, ties together the recurring words seen throughout the exhibition: Carpe Diem, enjoy life while you can, as it can come to a sudden end.

The exhibition recreated the feel of Pompeii, including the recreation of a fountain with sound effects, which enhanced the experience and engrossed the audience. The flow of the exhibition was smooth and easy to follow, but the lighting was quite dim, meaning that, on occasion, it was difficult to engage with some of the displays. Another slight flaw with the layout was that when there was an interesting piece on 
display, such as the Phoenix Tavern sign, it would attract a large agglomeration of people.

Ultimately, while this exhibition does cover the necessary aspects of food and drink in Pompeii, it consistently oversteps its boundaries, drawing attention to areas outside of what this exhibition is meant to cover and more towards the horror of the eruption of Vesuvius and the wider Roman world. In effect, while the resin cast and theme of death are entertaining, this gory spectacle is something the Romans would have gone to the amphitheatre to view - not the dining room!

\section{List of illustrations}

Figure 1: Mosaic of skeleton carrying wine jugs, Naples Museum inv. 9978, from Pompeii https://commons.wikimedia.org/wiki/File:Carpe_Diem_MAN_Napoli_Inv9978.jpg accessed 23 March 2020

To cite this paper please use the following details: Summers, E., Nawaz, S., Dale, E., Seager, G., Novis, P., Coster, M., Jenkins, M., Hill, C \& Sutherland, D (2020), 'Exhibition Review: Last Supper in Pompeii - Too much death, not enough food', Reinvention: an International Journal of Undergraduate Research, Volume 13, Issue 1, https://reinventionjournal.org/article/view/588. Date accessed [insert date]. If you cite this article or use it in any teaching or other related activities please let us know by emailing us at Reinventionjournal@warwick.ac.uk. 